\title{
Susan Lee Lindquist (1949-2016): It is personal
}

\author{
Lawrence E. Hightower ${ }^{1}$
}

Published online: 4 January 2017

(C) Cell Stress Society International 2017

It was Saturday, October 29, 2016. I was sitting at the organizers' table waiting for the opening of the Eighth International Symposium on Heat Shock Proteins in Biology and Medicine, held at the Hilton Old Town Alexandria, VA. Our Principal Organizer, Stuart Calderwood, walked in the room and sat down next to me. He leaned toward me and whispered "Susan Lindquist has died". Stuart is a professor at Brigham and Women's Hospital where she died. The news came as a shock, as we did not know that she had been terminally ill. Susan supported this symposium series with her characteristic enthusiastic and mind-expanding talks since its early gatherings at the Marine Biological Laboratory in Woods Hole. When she could not attend, she would send a senior member of her lab to participate. There was always a session on Hsp90 to attract her attention, and since its creation this particular meeting has maintained an eclectic bent, a surprising new direction, an unexpected model system, an unsuspected new result, so characteristic of Susan's own path through science.

We wanted to do something to memorialize Susan's life and professional contributions. Many of us were feeling the need to come together to express both our gratitude for all that Susan had done for our science and to relieve some of the sadness over the loss of a wonderful colleague and friend. We decided to begin the symposium banquet with a champagne toast in remembrance. Stuart Calderwood gave the eulogy and led the toast with eloquent words of praise for Susan and of comfort for her family, friends, and colleagues (Fig. 1).

Lawrence E. Hightower

Lawrence.Hightower@uconn.edu

1 Department of Molecular and Cell Biology, University of Connecticut, Storrs, CT 06269-3125, USA
I met Susan in 1982 at the inaugural Cold Spring Harbor meeting on Heat Shock. Her talk was about heat-shock regulation in Drosophila and Yeast. Ironically, we had overlapped in the same department in graduate school at Harvard University in the early 1970 s but did not meet. This was mainly because I was drafted into the US Army early in my second semester and sent to Vietnam. By the time I returned to Harvard, Susan had started her Ph.D. thesis research in Matthew Meselson's laboratory, and I was spending most of my time at Harvard Medical School in Boston, so I rarely visited the Biological Laboratories in Cambridge after that. In autobiographical writings, Susan tells the story of how Professor Meselson was rarely available to her when she was looking for a thesis topic as he was busy with chemical and biological warfare issues. In another twist of fate, I was sitting at lunch with Mat Meselson in the old Hotel Continental in downtown Saigon about the same time, discussing how the defoliant Agent Orange was being used to destroy old growth mangrove forests in South Vietnam. Mat went on to complete a very important study proving that Agent Orange had been sprayed on the crops of civilians as well as enemy combatants in Vietnam. But his best achievement from that time may have been to foster the successful completion of Susan's graduate program.

Susan, then Susan Lee Lindquist McKenzie, successfully defended her Ph.D. thesis entitled "Protein and RNA synthesis induced by heat treatment in Drosophila melanogaster tissue culture cells" at Harvard University in 1976. I know this because I requested a copy of her thesis through the University of Connecticut interlibrary loan a couple of years later. My student and I read it cover to cover. It took some courage to work on Drosophila heat shock in those days because quite a few biologists considered it a laboratory artifact at worst and a "curiosity of Drosophila biology" at best, a statement I heard more than a few times! I later learned that Susan was seeking a 

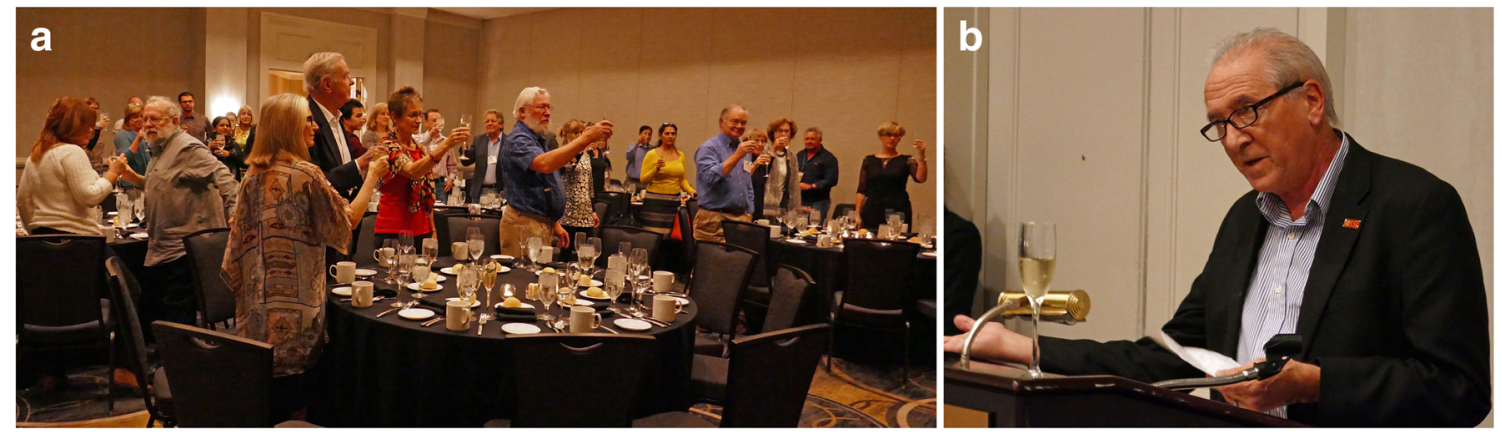

Fig. 1 Expression of gratitude for Susan's life and career. a Celebratory toast by the participants at the banquet during the Eighth International Symposium on Heat Shock Proteins in Biology and Medicine. b Principal Organizer Stuart Calderwood gave the eulogy and the toast

model in which to study eukaryotic chromosomes and heard about the heat shock response from a junior faculty member on the hall. I first learned about Susan's thesis work when my best friend in graduate school, Thomas Cline, stopped by my home in Storrs, CT, for some Thanksgiving dinner. We always chatted about our research during the rare occasions when we were together. The laboratory where Tom did his thesis research at Harvard was practically next door to the Meselson lab where Susan worked. Remarkably, both Tom and Susan went on to receive the US National Medal of Science for their path-breaking studies. I told Tom about a small set of proteins that I had discovered recently in cultured chicken embryo cells treated with amino acid analogs. I described what little I knew about these proteins, hardly more than their molecular weights and that they were rapidly and selectively synthesized, and he immediately said "They sound like the Drosophila heat shock proteins!" Then he told me to look up Susan's work. Her thesis helped to convince me that I should pursue these inducible proteins. There was something about the way Susan wrote about the response in her thesis that fortified my thoughts that this response could be something very important biologically, not just a handy system for studying eukaryotic gene regulation, a popular thought then. Very quickly, we verified that heat shock and amino acid analogs induced the same small cohort of proteins in cultured Drosophila, avian, and mammalian cells. It was then that I became a life-long fan of Susan's approach to science.

By the 1982 CSH meeting, Susan already had begun investigating the heat shock response in yeast in an effort to develop a more robust eukaryotic cell model. She had solidified further her belief that this response was a natural biological response of many if not all organisms. In the conclusions of her symposium paper, she wrote "In this regard it is particularly intriguing that a massive induction of heat-shock genes occurs in cells that have never been exposed to heat, as part of the developmental process of sporulation. This finding greatly strengthens the argument that heat-shock proteins play a natural biological role in the acquisition of thermotolerance." Susan and I were both "big picture" thinkers, and we enjoyed that aspect of each other's writings. It is well known that
Susan was fully capable of reductionist thinking of course. I suspect that doing one without the other just was not stimulating enough intellectually for Susan.

I discovered much later, while reading a mostly autobiographical article that Susan had written, that this period in the early 1980s had been a critical time in her developing career. She was trying without success to obtain federal funding for the yeast work. She wrote that she would likely have left academic research at that point if her last efforts to obtain a grant for her yeast project failed. My hands were probably shaking as I read Susan's words because I knew the backstory about her grant proposals to NSF! I was funded through the Cell Biology Program during that time. Jack Pate was the rotating program director and Gertrude Kasbekar was the associate director. They were looking to expand the expertise of the panel beyond ultrastructural analyses with grants and review panel appointments. My grant about cellular stress responses in avian and mammalian cells fit the bill as cellular biochemistry/physiology, and I became a panelist. During a meeting of our panel, the director of the Eucaryotic Genetics Program, DeLill Nasser, arrived with a proposal on which she wanted our advice. We were asked to read it overnight and discuss it the next day. The proposal, written by a young assistant professor at the University of Chicago named Susan Lindquist, was about the yeast heat shock response. It had been sent back to Susan by the genetics panel for revision, and upon its return, the revised proposal was sent out from mail-in reviews. I could hardly believe my eyes when I saw the reviews. The recommendations were all excellent. What were they waiting for? DeLill went on to explain that the genetics panel was not willing to fund a new model for heat shock response studies. But this day brought one of those fortunate confluences. DeLill was known for going the extra mile to find funding for geneticists, especially young scientists. Gert had the same passion for helping early career scientists. I was the only one on the panel that day who knew the exceptional quality of Susan's work firsthand. My main point to the panel was that the question of whether or not to fund a new model system was largely irrelevant in comparison to the opportunity to fund an excellent young scientist who had 
submitted an excellent proposal. Everything necessary came together and the proposal was funded. I am certain that this was my best panel work ever! Sadly, Jack, Gert, and DeLill are all deceased now. In my last phone conversation with Susan, about 2 years ago, I mentioned that I had a story about NSF that I wanted to tell her over a beer at the bar next time we met. Sadly, I did not have that opportunity.

I do not know whether or not Susan would have followed through with her thoughts of leaving research, but I do know that Susan was a risk-taker in her approach to science. I firmly believe that in order to dramatically impact a field of research and to push it in new directions, one must take risks. In the process, Susan expanded our field and even reinvented parts of it to include prions and prion-like proteins, diseases of protein folding, a new concept in evolutionary biology involving stress proteins as buffers for mutational events, yeast as a platform for drug development, nanotechnologies, and the list goes on!

When Cell Stress \& Chaperones was launched in 1995 as a Churchill-Livingstone journal, Susan was a founding member of the Board of Reviewing Editors. She participated in the initial editorial board meetings held in the board room at Cold Spring Harbor Laboratory during the heat shock meetings. In the summer of 1999 , something very unexpected occurred.

We were informed by our publishing editor at ChurchillLivingstone that our journal would cease publication at the end of 1999. We were told that another publisher had acquired them, and that decisions had been made about which journals to keep and which to terminate. My managing editor Helen Neumann and I decided we were going to fight to preserve the journal. We rapidly organized and registered in the US a nonprofit scientific society, the Cell Stress Society International. Colleagues, especially in Europe and India, had been discussing the need for a society in our field in order to broaden the venues and topics of our heat shock meetings. Now, we also needed an entity that could legally own the journal. All of this was accomplished with the help of Peter Csermely working from Hungary as the acting secretary-treasurer. The next challenge was to convince Churchill-Livingstone to transfer the ownership of the journal to the CSSI instead of permanently inactivating the journal. I called Susan and explained our situation and asked for her support. She wrote a very strong letter to our publisher in support of our request for them to transfer ownership of the journal to the CSSI. She laid out in clear language that there would be repercussions from within the scientific community if they declined to cooperate with our request. We had retained a psychologist with a deep knowledge of the publishing industry to advise us. He assured us that a letter from a notable scientist like Susan would be very helpful. He reminded us on several occasions that publishers depended on the cooperation of this community of authors and reviewers, and they would not risk alienating them. With Susan's help then, we finally prevailed and ownership of Cell Stress \& Chaperones was transferred to the CSSI where it resides to this day.

In 2003, Susan was awarded the CSSI Medallion in recognition of career achievement (Fig. 2). Takashi Yura, the first recipient of the medallion, came to Quebec from Japan to help us award the medallion to Susan. She then delivered a rousing address to the participants of First International Congress on Stress Responses in Biology and Medicine. She so enjoyed seeing old friends from the early days of our field and listening to the presentations that she extended her stay at the meeting several days (Fig. 3). I am proud of the fact that the CSSI recognized her remarkable accomplishments and contributions to our field well before Susan received some of her most prestigious awards.

We did not have phone conversations often, but when we did, they usually covered a range of topics. There was always a bit of science. Upon my request and shortly after it was created, Susan sent us frozen cells of her 7.10 hybridoma that made anti-HSP70 antibodies with broad reactivity to HSP70 family proteins in a variety of species, still one of the most useful antibodies available. A few months passed and I received a call from Susan, they had lost the hybridoma during
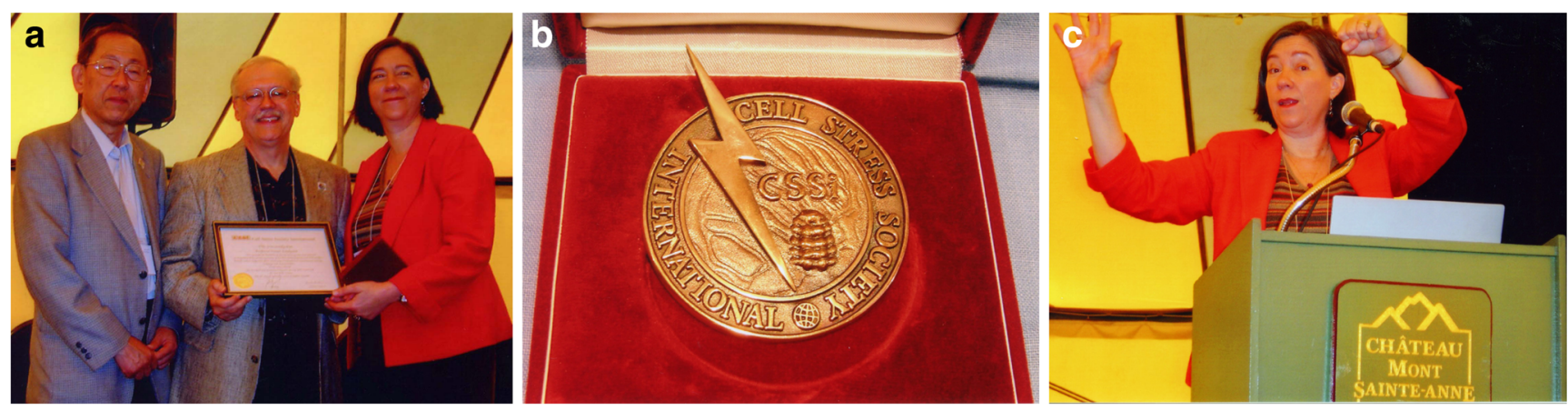

Fig. 2 Presentation of the CSSI medallion to Susan L. Lindquist followed by her keynote address at the First CSSI International Congress on Stress Responses in Biology and Medicine, held in 2003 at the Château Mont Sainte-Anne, Québec. a Presentation of the award to Susan by CSSI medalist Takashi Yura and Lawrence Hightower, secretary-treasurer of the CSSI. b The CSSI medallion for career achievement. c Susan giving the keynote address 


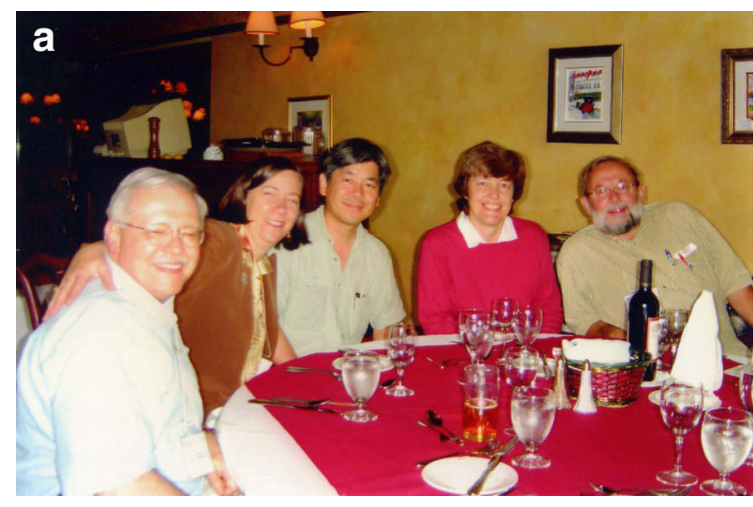

Fig. 3 Susan extended her stay at the Congress to enjoy time with old and new friends and colleagues. a Luncheon following the keynote session with (left to right) Lawrence Hightower, Susan Lindquist, Richard Morimoto, Robin Anderson, and Principal Organizer Robert

a freezer failure and would I send them some of our cells? I was very happy to reward her original generosity with gratitude. We talked about the value and need for collegiality in science.

We shared the habit of buying rocks and fossils in places to which we traveled for meetings. We both liked to dance, and we both appreciated a great tango as well as the contra dances shared during the Cold Spring Harbor meetings. During one conversation, we got onto the topic of oriental rugs. I mentioned that I had recently bought an amazing vegetable dyed

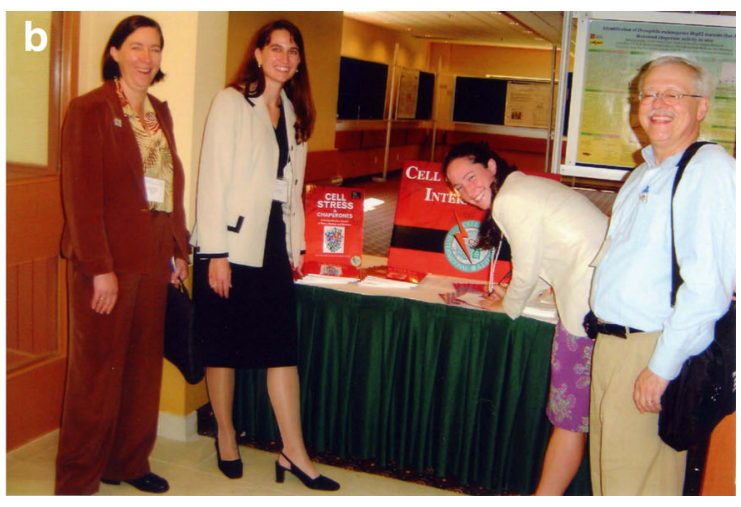

M. Tanguay. b Visit to the Cell Stress \& Chaperones/CSSI table by (left to right) Susan Lindquist, Allen Press representative Kerry Velilla, graduate student Emily Noonan, signing up to join the Society, and Lawrence Hightower

oriental. Susan said that she was looking to buy one, but she did not want to support weavers that used child labor and merchants that sold those rugs. I told her about a shop that did not condone child labor, Yayla Tribal Rugs, a small shop on Broadway just a couple blocks from her office at the Whitehead Institute at MIT. I also told her about their nonprofit organization Barakat, and how they funded schools for young girls and clinics in India, Pakistan, and Afghanistan. "Thanks, this is great!" she said. Susan was a dedicated humanitarian as well as a remarkable scientist. She will be greatly missed. 